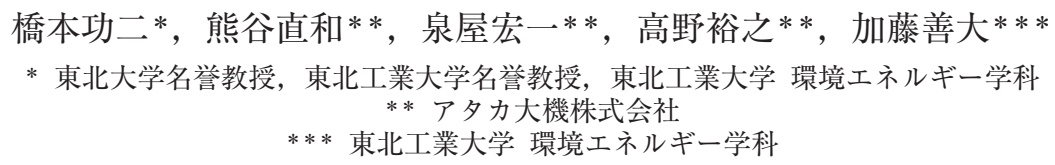

The Use of Renewable Energy in the Form of Usable Fuel via Hydrogen

\author{
Koji Hashimoto*, Naokazu Kumagai**, Koichi Izumiya**, Hiroyuki Takano** and Zenta Kato*** \\ * Professor Emeritus of Tohoku University and Tohoku Institute of Technology \\ ** Daiki Ataka Engineering, Co., Ltd. \\ *** Department of Environment and Energy, Tohoku Institute of Technology
}

\begin{abstract}
Extrapolation of world energy consumption from 1990 to 2008 will result in the complete exhaustion of world reserves of oil, natural gas, uranium and coal until 2040, 2046, 2048 and 2054, respectively. For the survival of all people in the whole world, intermittent and fluctuating electricity generated from renewable energy should be supplied in the form of usable fuel to all people in the whole world. We are proposing global carbon dioxide recycling for the use of renewable energy in the form of methane via electrolytic hydrogen generation using carbon dioxide as the feedstock. We created energy-saving cathodes for hydrogen production, anodes for oxygen evolution without chlorine formation in seawater electrolysis and catalysts for methanation of carbon dioxide and built the pilot plants of industrial scale. Recent advance in materials is described. The industrial application is in progress.
\end{abstract}

Key words : Renewable energy, methane supply, $\mathrm{CO}_{2}$ recycling, electrolytic hydrogen generation, $\mathrm{CO}_{2}$ methanation, fuel depletion, survival of world population

\section{1. エネルギーの将来}

私たちが 20 年以上にわたり研究開発して来たグロー バル二酸化炭素リサイクルも産業としての開発が始まろ うとしている。この主題については，2009年に本誌で紹 介した1)。これに関連する, 材料とシステムなどその後 の展開を述べるにあたり，まず，石油，天然ガス，石炭， ウランが制限なく購入できる今, エネルギーの何が問題 か，から考えてみたい.

アメリカ合衆国エネルギー省エネルギー情報局（DOE） のウエブサイトに, 1980 年から 2008 年までの世界の全 ての国と地域のエネルギー消費量, 炭素排出量, 人口な どの最新のエネルギー関連データが, 石油, 天然ガス, 石炭などの埋蔵量に加えて揭載されている2). 図 1 は, 3 つの国のグループと合わせて日本人，アメリカ人，中国 人の一人一人が 28 年間エネルギーをどのように消費し てきたかを示したものである．個人消費量の違いは一目 瞭然である。このうち 2008 年について, 個人消費量と 人口の関係をまとめたものが図 2 である.人口ではマイ ノリティーの先進国の人々が, 世界のエネルギーの半分 近くを消費し，世界の人口の $78 \%$ 近くを占める途上国の 人々は世界のエネルギーの $42.8 \%$ しか使っていない. 例 えば世界平均までエネルギーを消費してよいといわれる と, 途上国の人々は 2 倍近くまでエネルギー消費量を増 やすことができるが，アメリカ人が $78 \%$ ，日本人が

\footnotetext{
*,*** 7982-8577 仙台市太白区八木山香澄町 35-1 (35-1, Yagiyama Kasumi-cho, Taihaku-ku, Sendai, 982-8577 Japan)

** ₹277-8515 柏市新十余二 11 (11, Shintoyohuta, Kashiwa, 277-
} 8515 Japan)

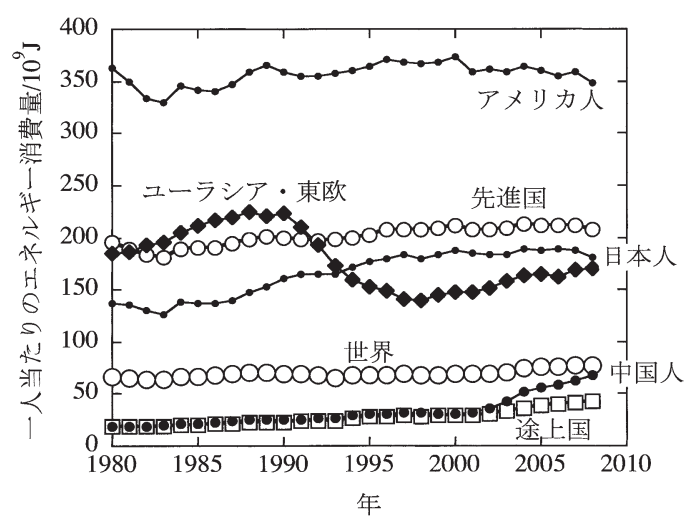

図 1 世界の 3 つのグループと日本人, アメリカ人, 中国人の 一人当たりのエネルギー消費量の 28 年間の変化 ${ }^{2)}$

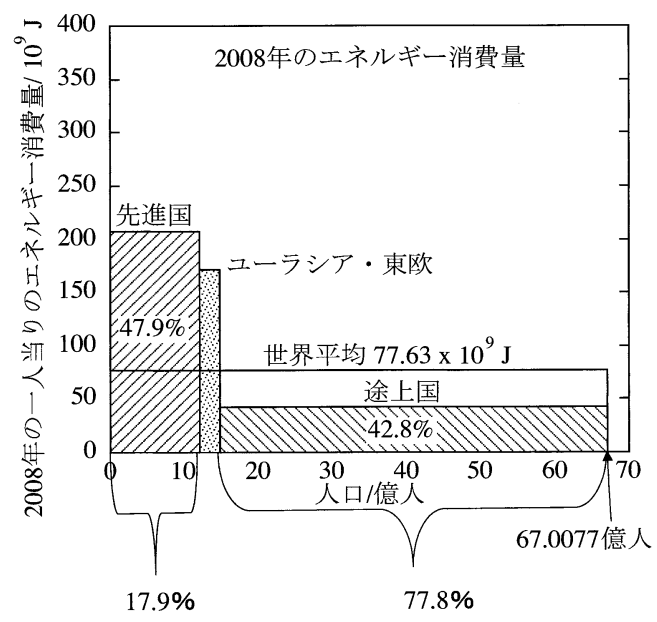

図 22008 年の世界の 3 つのグループの一人当たりのエネルギ 一消費量と人口 ${ }^{2}$ 
$58 \%$ 消費量を減らすことなど到底できない。先進国平均 でエネルギー消費を $2 / 3$ 減らし，ロシア東欧も半分以上 減らすことなどできるはずがない. 1997 年には京都議定 書が採択されたが，図 1 から分かるように，景気の変動 などの影響以外に，1980 年から 2008 年の間に先進国の 一人当たりのエネルギー消費量が減る傾向は全くなかっ た。ロシア東欧の一人当たりのエネルギー消費量は, 1988 年の最高時からソ連の崩壊の結果 1997 年には $62 \%$ まで落ち込んだが，その後は着実に増大し続け，2007 年 以降, アメリカ人を除く先進国の人々の 2007 年および 2008 年の年平均個人消費量 $160 \times 10^{9} \mathrm{~J} \mathrm{year}^{-1}$ を越えて増 え続ける傾向にある．世界の一人当たりのエネルギー消 費量がやがて先進国並みにまで増えることは当然であろ

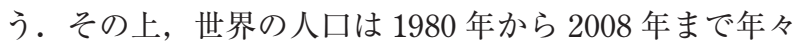
ほぼ 8 千万人ずつ見事な直線で増え続けている2). した がって，世界のエネルギー消費量が増え続けるのは，避 けがたい。

図 3 の左側には，28 年間の世界のエネルギー消費の歴 史を示した ${ }^{2)}$ ・ソ連崩壊以降の 1990 年から 2008 年の 18 年間をとっても，毎年 1.01943 倍ずつエネルギー消費は 増大している。この割合でエネルギー消費が増え続ける

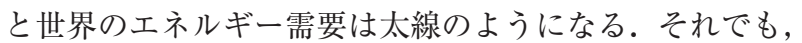
現在の人口増大率が続くと仮定すると， 2050 年に一人当 たり $116 \times 10^{9} \mathrm{~J} \mathrm{year}^{-1}$ 程度で，一人当たりでは現在の先
進国平均の半分に過ぎない. 2008 年の割合でエネルギー 供給が続くと, 2040 年には世界の石油埋蔵量を使い尽く す. 残る燃料だけを使えば，2046 年には天然ガスがなく なる.ウランもどの国にも使うことを許せば，540万ト ン3）の世界のウラン資源は，2048 年までしかもたない. 残る石炭も 2054 年でなくなる。例え新しい燃料を 2009 年当時の石油埋蔵量分だけの量見つけても，2060 年まで の空白も埋まらない。世界の化石燃料を燃やし尽くせば 温暖化は堪え難くなるであろう。実際には，産油国は自 分たちが生き残るために輸出を制限せざるを得なくなる ので, 石油の供給は遠くない将来減り始めるであろう. 事実， 2012 年 1 月 26 日には，インドネシアが輸出より 国内需要を優先するとして原油輸出の停止を検討してい ることが報じられた。

とは言っても, 石油, 天然ガス, 石炭, ウランが制限 なく購入できる現在, 再生可能エネルギーを使える形の エネルギーとして供給する技術は, 産業が今すぐ利益を 上げられるほど安くはない.しかし，燃料がなく温暖化 は堪え難いという悲惨な状態の到来を避けるためには, 世界中が再生可能エネルギーだけで生きて行くことがで きる技術を開発し，世界に普及しなければならない。こ れは, 石油供給が減り始める前のここ 15 年位の間に実 現しなければならず，今手が届く技術しか当てにはでき ない.

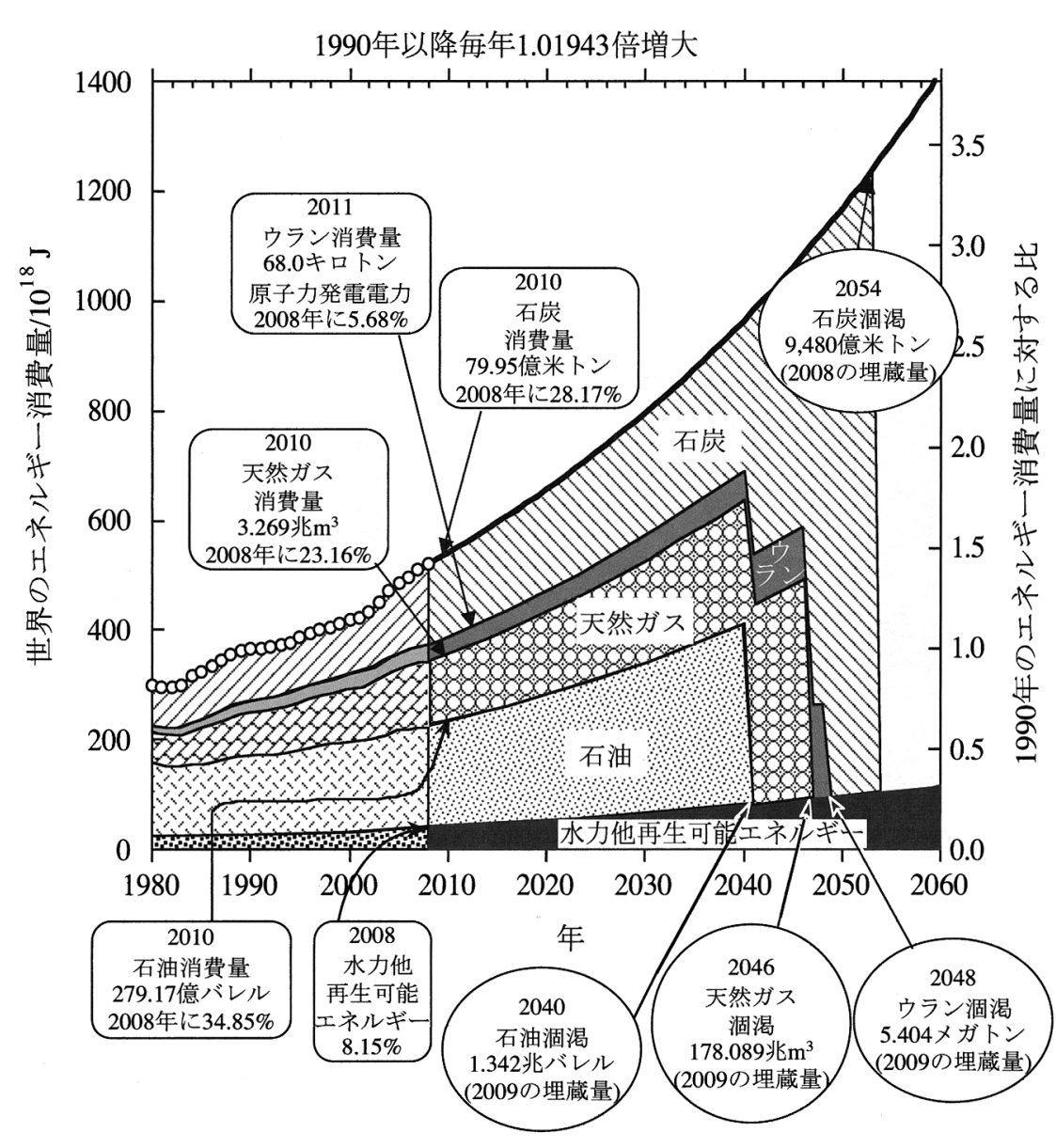

図 3 世界の 28 年間のエネルギー消費の歴史 2$)$ と 1990 2008 年のエネルギー消費量の増 大率が継続する場合の世界のエネルギー需要とそれを満たすエネルギー供給による 化石燃料とウランの涸渴年

ウランについては文献 3)，その他は文献 2) のデータを使用

\section{2. 再生可能エネルギー使用 のむずかしさ}

現在, 再生可能エネルギー利用 は, 小規模分散型が主力であって， これ自体は貴重な努力である。し かし, 世界中の人々がこの地球で 生き続けるためには, 消費するエ ネルギーを $100 \%$ 再生可能エネル ギーに置き換えなければならな い.十分なエネルギーを地球上で 得ることはできる。例えば, 2008 年に世界が消費した $520.158 \times 10^{18}$ $\mathrm{J}$ 年 ${ }^{-1}$ のエネルギーを電力の形で 造り出すには, $15 \%$ のエルギー 変換効率の太陽電池を $1000 \mathrm{~W} / \mathrm{m}^{2}$ の太陽光が得られる砂漠で 1 日 8 時間稼働させると, 地球の主な砂 漠のわずかに $2.04 \%$ 利用するだ けで十分である。このことは，私 たちを元気づけてくれる。

再生可能エネルギーを電力に変 える技術はすでにある。深刻な問 題は, 再生可能エネルギー起源の 電力の多くは, 変動・断続するこ とである. 変動・断続する電力を 電力会社が直接受け入れると, 配 電される電力に周波数変動がおこ る. 周波数変動が $\pm 0.2 \mathrm{~Hz}$ を越え ると, 企業から苦情が来る4)。鋼 板やアルミニウム板を造る産業で 
は, 圧延条件が変動し, 均一な厚さが得られない. 化学 繊維や製紙産業では巻き取り速度の摇らぎで，太くある いは厚くなったり切れたりする．石油産業では脱硫がう まく行かないなどと言われている ${ }^{4)}$. 日本では周波数変 動の限界を北海道電力が $\pm 0.3 \mathrm{~Hz}$ 以内, その他の電力会 社は土0.2 Hz 以内を目標にしていると言われている4). 北海道電力の試算では，最大出力の約 $4.8 \%$ である 2500 万 $\mathrm{kW}$ の風力発電を受け入れると, 周波数変動は $0.3 \mathrm{~Hz}$ を越えてしまうと報じられている5 $。$ 。このように，普通 の産業に支障を来すので，断続・変動する電力の形では, 電力会社の最大出力の $5 \%$ 程度しか, 電力会社には直接 は受け入れて貴えない.

したがって, 再生可能エネルギー起源の断続・変動す る電力は, 燃料に変換して供給しなければならない。

\section{3. グローバル二酸化炭素リサイクル}

1970 年代から，再生可能エネルギー起源の遠方の変 動・断続する電力を海水電解で水素に変えることを考え て来た。しかし，世界中にエネルギーを供給することを 考えると，水素を輸送し燃焼するインフラはなく技術も ないことに気が付いた。世界中が再生可能エネルギーだ けで生きて行くためには, 輸送と燃焼のインフラが世界 に普及している燃料に再生可能エネルギーを変えなけれ ばならない。

幸いにも，筆者らは 20 年以上も前に，二酸化炭素と 水素の反応で，迅速にほとんど 100\%メタンに変えるこ とができる触媒を見いだした，メタンは天然ガスの主成 分であって，輸送と燃焼のインフラが世界中に普及して いる.

この触媒が得られたことに基づいてグローバル二酸化 炭素リサイクルを提案した ${ }^{6)}$. 世界の人々に必要なエネ ルギーを砂漠の太陽電池で造りだす。断続するエネルギ 一を最寄りの海岸で海水電解を用いて水素に変える. 水 素を二酸化炭素と反応させ輸送と燃焼のインフラが世界 に普及しているメタンに変えて世界に供給する。現在と 唯一の違いは, 二酸化炭素を煙突から回収して, 電力が 得られる所まで送り返すことである。これが実現すれば， 太陽エネルギーを永久に使い続け，二酸化炭素は決して 大気に排出せずに，燃料の貴重な原料として使い続ける ことができる。

この実現のためには，再生可能エネルギーから発電す る技術はある。メタンの輸送と燃焼のインフラもある. 二酸化炭素を煙突から回収する技術は既に, 産業で試さ れている. 液化二酸化炭素の特性は, 液化石油ガスに類 似しているため LPG の輸送のインフラが液化二酸化炭素 の輸送には使うことができる。したがって, 海水電解に よる水素製造と二酸化炭素のメタン化を産業に出来る技 術を開発すれば，グローバル二酸化炭素リサイクルは実 現する。

\section{4. グローバル二酸化炭素リサイクルの キーマテリアル}

グローバル二酸化炭素リサイクルのキーマテリアル は, 海水電解の陰極と陽極, 二酸化炭素メタン化の触媒
である。

\section{1 海水電解の陽極}

産業で行われている $\mathrm{NaCl}$ 水溶液の電解は, ソーダ工 業においても, 次亜塩素酸ナトリウムを製造する海水滅 菌用海水電解においても, 陽極では塩素を製造すること が目的である。しかし，大量の燃料の製造に大量の塩素 を発生することは許されない。海水電解であっても, 塩 素を発生せず，水電解と同様に酸素を発生する電極が必 要であった。これは，マンガンを主体にモリブデン，夕 ングステン，スズ，鉄などを含む複酸化物を電極活物質 とすることで実現した7'-10).

陽極は, 導電体基板にチタンを用い, チタンのアノー ド酸化を防止するため, $\mathrm{IrO}_{2}$ のような導電性酸化物を被 覆した不溶性陽極に, 更に塩素を発生せず酸素のみを発 生する電極活物質を被覆した三層構造からなっている.

電極活物質は, 必要な陽イオンを含む $\mathrm{MnSO}_{4}$ 溶液中 で不溶性陽極をアノード分極し, $\mathrm{MnO}_{2}$ 型の複酸化物を 不溶性陽極上にアノード電着して造る。これは，アノー ド分極して酸素を発生する電極活物質を電着する方法で あるから, 電着の際, 激しい酸素発生を伴う。酸素の気 泡が付着して留まる部分は, 電極活物質は成長しないた め, 電極活物質は多孔質である。図 4 は $\mathrm{Mn}_{1-x-y} \mathrm{Mo}_{x}$ $\mathrm{W}_{y} \mathrm{O}_{2+x+y}$ を電極活物質として, 活物質作製のアノード電 着の時間と回数を変えた場合に電極寿命がいかに変わる かを示したものである ${ }^{11)}$ 。連続してアノード電着を行っ た場合，電着を 30 分行なったものに比べて，電着時間 を 60 分に延ばしてもほとんど寿命は延びず，90 分も続 けると返って短寿命になっている。アノード電着の際, 酸素気泡が付着したままのところでは, 電極活物質は成 長しないため, 孔になる。この孔は, 連続して行う電着 の時間が長くなって電極活物質が厚くなる程深くなる. この電極を $\mathrm{NaCl}$ 水溶液の電解に用いると, 電極活物質 の酸化物が薄く電気抵抗が低い孔の底で酸素が発生しや すい. 気泡が抜けにくい深い孔ほど酸素の気泡の圧力が 高くなって活物質が破壊されやすく, 破壊されれば中間 層から塩素が発生する。このため, アノード電着による 電極活物質の作製を連続して長時間行うと, 電極活物質

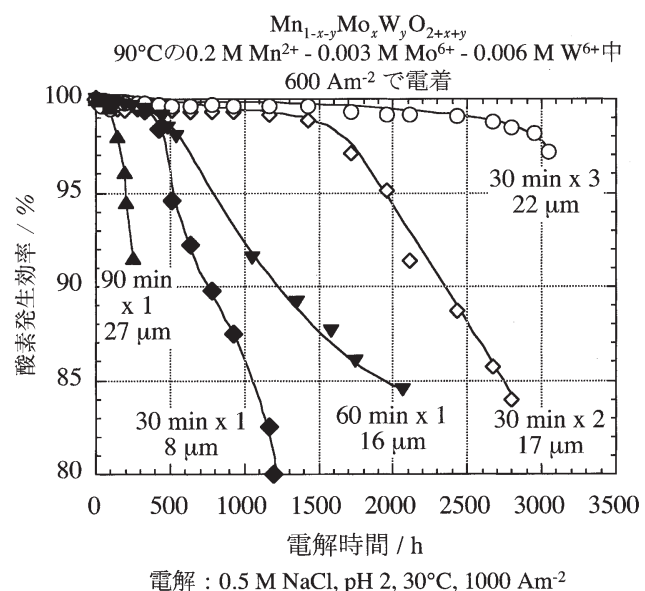

図 $4 \mathrm{IrO}_{2}$ を中間層とし $\mathrm{Mn}_{1-x-y} \mathrm{Mo}_{x} \mathrm{~W}_{y} \mathrm{O}_{2+x+y}$ を電極活物質とす る陽極を用い $\mathrm{pH} 2,30^{\circ} \mathrm{C}$ の $0.5 \mathrm{M} \mathrm{NaCl}$ を $1000 \mathrm{Am}^{-2}$ の電 流密度で電解した場合の電極活物質をアノード電着した 時間と回数による酸素発生効率の変化 ${ }^{11)}$ 
が破壊されやすく，返って寿命は短くなる。これに対し 30 分，アノード電着を行なった後電極を洗浄乾燥し, 改 めて 30 分のアノード電着を繰り返すと, 先に生じた孔 の上を新しい電極活物質が覆うことが出来るため活物質 が厚いほど寿命は長くなっている。このような知見は， 科学的には面白くないが，このような構造と機能の物質 を造る場合に役に立つ.

長時間使用した場合に，中間層の厚さが不均一な電極 の寿命を決めるのは，酸素発生のアノード分極の間に， 電極活物質複酸化物と, $\mathrm{IrO}_{2}$ のような中間層の中を内方 に拡散する酸素によって, 中間層の薄い部分で基板のチ タンの表面が局部的に酸化され，膨れて電極活物質が壞 れたところから塩素が発生することによる．中間層 $\mathrm{IrO}_{2}$ の作製は $\mathrm{H}_{2} \mathrm{IrCl}_{6}$ ブタノール溶液などをチタン基板に刷 毛塗りし, $80^{\circ} \mathrm{C}$ で 10 分乾燥後 $450^{\circ} \mathrm{C}$ で 10 分焼成を 3 回 繰り返し, 最後の焼成は 60 分続けることによって行っ て来た. $\mathrm{H}_{2} \mathrm{IrCl}_{6}$ ブタノール溶液は粘性が高く, 生じる $\mathrm{IrO}_{2}$ が均一になりにくいため, 十分な寿命が得難い. $\mathrm{SnO}_{2}$ は $\mathrm{IrO}_{2}$ と同じルチル構造であるため, $\mathrm{H}_{2} \mathrm{IrCl}_{6}-$ $\mathrm{SnCl}_{4}$ 混合ブタノール溶液を用いて中間層を作製すると, $\mathrm{Sn}_{1-} \mathrm{Ir}_{x} \mathrm{O}_{2}$ のルチル型単相複酸化物が生じ，これは均一 性が高い中間層となる。図 5 は中間層として $\mathrm{IrO}_{2}$ と $\mathrm{Sn}_{1-} \mathrm{Ir}_{x} \mathrm{O}_{2}$ を用いた場合の, 電極寿命の比較である ${ }^{12)}$. $\mathrm{IrO}_{2}$ 層は不均一なため, $\mathrm{Sn}_{1-}{ }_{x} \mathrm{Ir}_{x} \mathrm{O}_{2}$ の作製に用いた溶液 と同じ濃度の $0.1 \mathrm{M} \mathrm{H}_{2} \mathrm{IrCl}_{6}$ ブタノール溶液を用いたので は, $0.5 \mathrm{M} \mathrm{NaCl}$ の電解を 40 分行うと酸素発生効率は $96 \%$ ま゙低下してしまう。 $0.52 \mathrm{M} \mathrm{H}_{2} \mathrm{IrCl}_{6}$ ブタノール溶 液を用いて中間層の平均厚さを 5 倍以上にして, 初めて 99\%以上の酸素発生効率を 2500 時間維持できる電極と なる。これに対し， $\mathrm{Sn}_{1-}{ }_{x} \mathrm{Ir}_{x} \mathrm{O}_{2}$ を中間層とすると，中間 層の厚さが $\mathrm{IrO}_{2}$ 層の $1 / 5$ 以下であっても，電極寿命は 4200 時間を越えてはるかに長い. 電気抵抗の大きな酸化 物の厚さを薄くできることはそれだけでも実用的に重要 である。

しかし，いかに均一な厚さの酸化物で覆われた電極で あっても, 酸素の拡散障壁としての能力が十分ではない
酸化物の中間層と電極活物質からなる電極をアノードと して酸素発生に用いると，アノード分極の間に，酸素が 両層を経て内方に拡散し，基板のチタンを酸化させる. 均一な $\mathrm{TiO}_{2}$ の成長は電極の電気抵抗の増大となって現 れる。

酸化物電極は，金属電極の分極挙動の常識からは伺え ない分極挙動を示す. 通常, 測定電位への溶液抵抗の寄 与は，パルス幅と周期をそれぞれ $6 \mathrm{msec}$ および $12 \mathrm{msec}$ 程度にした電流遮断法で金属電極と同様に補正してき た。ところが，このような短時間では，酸化物層の放電 は検知できる程には起こらず，電流遮断法で補正後にも， 酸化物の電気抵抗と電流の積の量だけ大きな電圧が観測 される. 図 6 は図 5 で 4200 時間を越えて $99.9 \%$ の酸素 発生効率を示した電極を用い，電解前，および $\mathrm{pH} 1$ の $0.5 \mathrm{M} \mathrm{NaCl}$ 中 $1000 \mathrm{Am}^{-2}$ での電解 120 時間後および 1000 時間後に，同じく $\mathrm{pH} 1$ の $0.5 \mathrm{M} \mathrm{NaCl}$ 中で測定した 分極曲線である.この分極曲線は, 上述のような電流遮 断法で補正したものである。電解時間が長いほど電流が 大きいほど観測される電位が大きくなっているのが認め られる。

金属電極であろうと酸化物電極であろうと, 酸素発生 過電圧が十分に高いところでは, 電流密度 $i$ と酸素発生 の過電圧 $E_{\text {reaction }}$ は近似的に(1) 式のように表される.

$$
\begin{aligned}
& \log i=\log i_{0}+E_{\text {reaction }} / b \\
& E_{\text {reaction }}=b\left(\log i-\log i_{0}\right)
\end{aligned}
$$

ここで $i_{0}$ は $E_{\text {reaction }}=0 \mathrm{~V}$ のときの電流密度, $b$ は Tafel 勾配である. Tafel 勾配は反応機構で変わり， $i_{0}$ は陽極の 活性と反応機構の影響を受ける.

水分子から酸素を分離する電流は，電極基板から中間 層を経て電極活物質表面に到達する．酸化物陽極の電気 抵抗が無視できない場合には, 電流 $i$ が酸化物電極表面 に到達するまでに電圧損失 $E(r){ }_{\mathrm{i}}$ が起こる．酸化物の電 気抵抗が $r$ であとき, $E(r)_{\mathrm{i}}$ は

$$
E(r)_{\mathrm{i}}=i r
$$

である。したがって，酸素過電圧 $E_{\text {reaction }}$ は，ir と $\mathrm{msec}$ レベルの電流遮断法で推定される主として溶液抵抗 $R$ に

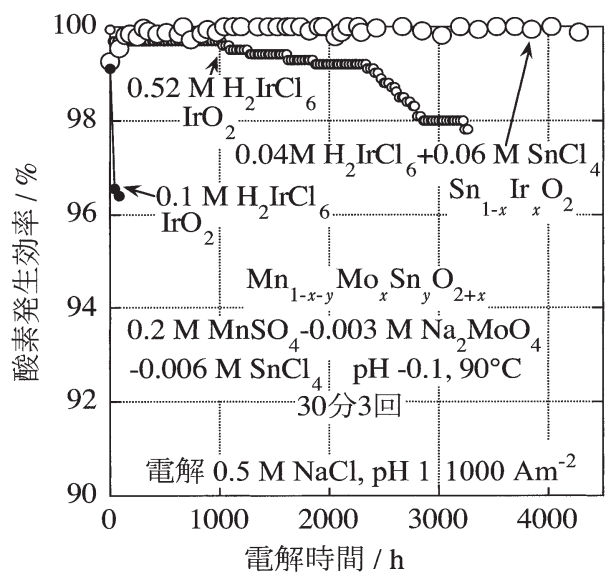

図 5 中間層に $\mathrm{IrO}_{2}$ と $\mathrm{Sn}_{1-x} \mathrm{Ir}_{x} \mathrm{O}_{2}$ を用い電極活物質 $\mathrm{Mn}_{1-x-y}$ $\mathrm{Mo}_{x} \mathrm{Sn}_{y} \mathrm{O}_{2+x}$ を 30 分 3 回アノード電着して作製した電極を 用い, $\mathrm{pH} 1$ の $0.5 \mathrm{M} \mathrm{NaCl}$ を $1000 \mathrm{Am}^{-2}$ の電流密度で電解 した場合の酸素発生効率の変化 ${ }^{12}$

$\mathrm{IrO}_{2}$ は $0.1 \mathrm{M} \mathrm{H}_{2} \mathrm{IrCl}_{6}$ および $0.52 \mathrm{M} \mathrm{H}_{2} \mathrm{IrCl}_{6}$ から作製 $\mathrm{Sn}_{1-x} \mathrm{Ir}_{x} \mathrm{O}_{2}$ は $0.04 \mathrm{M} \mathrm{H}_{2} \mathrm{IrCl}_{6}+0.06 \mathrm{M} \mathrm{SnCl}_{4}$ から作製

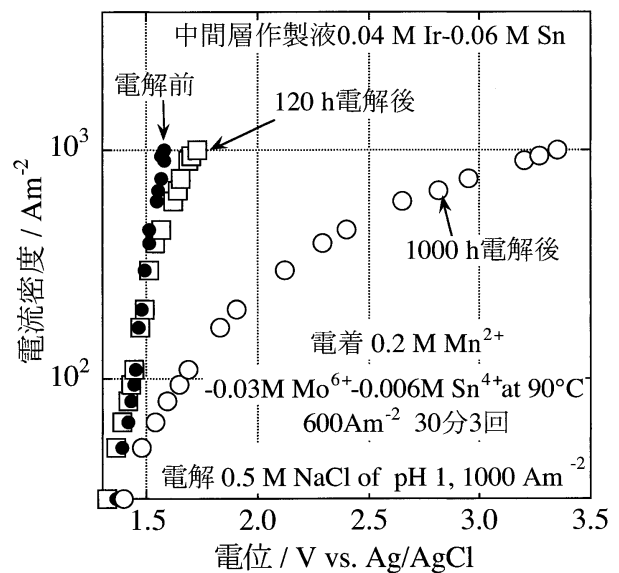

図 $60.04 \mathrm{M} \mathrm{H}_{2} \mathrm{IrCl}_{6}+0.06 \mathrm{M} \mathrm{SnCl}_{4}$ から作製した $\mathrm{Sn}_{1-x} \mathrm{Ir}_{x} \mathrm{O}_{2}$ を中 間層とし, $\mathrm{Mn}_{1-x-y} \mathrm{Mo}_{x} \mathrm{Sn}_{y} \mathrm{O}_{2+x}$ 電極活物質を 30 分 3 回ア ノード電着して作製した電極，およびこれを用いて $\mathrm{pH} 1$ の $0.5 \mathrm{M} \mathrm{NaCl}$ を $1000 \mathrm{Am}^{-2}$ の電流密度で 120 時間および 1000 時間電解した後の pH 1 の $0.5 \mathrm{M} \mathrm{NaCl}$ で測定した定 電流分極曲線 12 
基づく $i R$ との和の分だけ, 観察される $E_{\text {observed }}$ より低い.

$$
E_{\text {observed }}=E_{\text {reaction }}+i r+i R
$$

観測される電位は

$$
\begin{aligned}
E_{\text {observed }} & =E_{\text {reaction }}+i r+i R \\
& =b\left(\log i-\log i_{0}\right)+i r+i R
\end{aligned}
$$

である。言い換えると, 観測される電極電位は酸素過電 圧と陽極および溶液の抵抗に基づく電圧損失分の和であ る.

二つの電極 $\mathrm{A}$ と $\mathrm{B}$ 上で, 酸素発生反応が同じ機構で起 こり Tafel 勾配 $b$ が等しいとき, 電流遮断法で溶液抵抗 分を補正した後の測定電位を改めて $E_{\text {observed }}$ とすると,

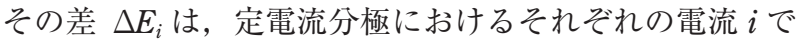
は式(5)のようであろう。

$$
\begin{aligned}
\Delta E_{i} & =E_{\text {observed }}(\mathrm{A})_{i}-E_{\text {observed }}(\mathrm{B})_{i} \\
& =b\left(\log i_{0 \mathrm{~B}}-\log i_{0 \mathrm{~A}}\right)+i\left(r_{\mathrm{A}}-r_{\mathrm{B}}\right)
\end{aligned}
$$

ここで $r_{\mathrm{A}}$ と $r_{\mathrm{B}}$ は陽極 $\mathrm{A}$ と B の電気抵抗である. $\Delta E_{i}-$ $i$ のプロットが直線であれば, 二つの電極上での電気化 学反応は同じ機構で起こり, 直線の勾配 $\partial\left(\Delta E_{i}\right) / \partial i$ は二 つの電極の電気抵抗の差に相当する.

$$
\partial\left(\Delta E_{i}\right) / \partial i=r_{\mathrm{A}}-r_{\mathrm{B}}
$$

図 6 に示した $1000 \mathrm{Am}^{-2}$ の電流密度で $\mathrm{pH} 1$ の $0.5 \mathrm{M}$ $\mathrm{NaCl}$ 中 120 時間および 1000 時間電解後に, 同じ $\mathrm{pH} 1$ の $0.5 \mathrm{M} \mathrm{NaCl}$ 中で測定した定電流分極曲線と電解前の定電 流分極曲線のそれぞれの電流密度における電位の差 $\Delta E_{i}$ と分極曲線測定の電流密度との関係を図 7 に示す。この 図は式 (5)に対応し，しかも共に原点を通る直線である. 電解を続けても, 電極表面は変わらず, 電極活物質も電 極活性も酸素発生反応機構も変わらなければ, $i_{0} や b$ は 変わらない.したがって, 当然

$$
b\left(\log i_{0(0 \mathrm{~h})}-\log i_{0(\mathrm{th})}\right)=0
$$

である.この図は電解中に基板のチタン上で酸化が進行 し, $1000 \mathrm{Am}^{-2}$ の電流密度で 1000 時間電解すると, 1000 $\mathrm{Am}^{-2}$ の電流密度を維持するには, 電解電圧を約 $1.8 \mathrm{~V}$ も 上げなければならないことを示している.

したがって，酸化物を電極活物質とする電極を用い， アノード分極して酸素を発生させる電解の場合, 酸化物 内を内方に拡散する酸素に対して有効な拡散障壁を造る ことが，省エネルギー電解の実用に向けての課題である.

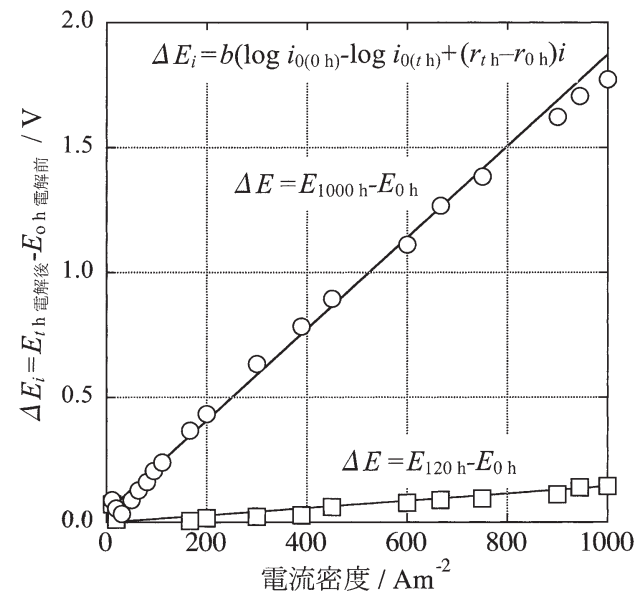

図 7 図 6 の 120 時間および 1000 時間電解した後の定電流分極 曲線の各電流密度における電位から電解前の分極曲線の 対応する電位を差し引いた $\Delta E_{i}$ と電流密度 $i$ の関係 ${ }^{12}$
また，世界に燃料を供給するための大規模電解にイリジ ウムのような希元素は使えない。陽極の開発にはまだま だ解決しなければならないことがある。

さらに，緩衝能力のない中性の海水を電解する場合， 電解開始と同時に，水素発生で陰極液はアルカリ性にな り, 酸素発生で陽極液は酸性になる。 $\mathrm{pH}$ の差が 10 にな ると，それだけで電解電压は $600 \mathrm{mV}$ 上がってしまう. 水素イオン濃度は電解と共に直線的に変化するのに対し, $\mathrm{pH}$ は水素イオン濃度の対数で変化することを利用して, 電解液の流れを工夫する実験を行っている.

直接海水電解は, 海水から少量の水を貪うだけで, 行 うことができるグリーンな電解であるが, 酸化物陽極と 緩衝能力がない中性溶液の電解は未解決な問題が多く, まだ，電解のエネルギー消費量で，海水を淡水化して行 う高温アルカリ電解に勝てない.したがって, 実用プラ ントの場合, 高温アルカリ電解を安全に行うことが出来 る条件であれば, 現在は, 高温アルカリ電解を勧めてい る。

\section{2 陰 極}

海水電解であっても陰極液はたちまちアルカリ性にな るため, 陰極の開発には, $90^{\circ} \mathrm{C} の 8 \mathrm{M} \mathrm{NaOH}$ 溶液を用い てきた。前報1) に述べたように，ニッケルなどよりはる かに省エネルギーのニッケル基 ${ }^{13)}$ あるいはコバルト基 ${ }^{14)}$ の合金電極が得られている.

この電極は高温アルカリ電解にも使うことが出来る.

\section{3 二酸化炭素のメタン化 \\ 4.3.1 二酸化炭素メタン化用触蝶}

従来の触媒を用いる二酸化炭素と水素の反応は, 主生 成物が一酸化炭素であって, しかも反応がきわめて遅く 一酸化炭素で触媒が披毒して魅力的ではなかった。目的 は安い燃料を迅速大量に製造することであるから, 必要 なことは, 単純な反応器に原料の二酸化炭素と水素を供 給すれば，迅速に(8)式のようにメタンを製造し，一酸 化炭素などは決して生じないことである.

$$
\mathrm{CO}_{2}+4 \mathrm{H}_{2} \rightarrow \mathrm{CH}_{4}+2 \mathrm{H}_{2} \mathrm{O}
$$

前報1)に述べた内容を簡単にまとめる。アモルファス $\mathrm{Ni}-\mathrm{Zr}$ 合金を触媒前駆体として用い, 体積比で 1 対 4 の 二酸化炭素と水素を反応させると, $200 \sim 300^{\circ} \mathrm{C}$ で迅速に 二酸化炭素がほほ 100\%メタンに転換する理想的な触媒 が得られた ${ }^{15)}$. Ni-Zr 合金を, 触媒反応温度で二酸化炭 素と水素の混合ガスにさらすと, 合金中のジルコニウム は, $\mathrm{ZrO}_{2}$ 型の酸化物となり, ニッケルは金属状態を保つ. このため, 合金は $\mathrm{ZrO}_{2}$ 型酸化物にニッケルが担持され た触媒に変わる。したがって，実用的には合金に空気酸 化と水素による還元処理を施して触媒を得ることが出来 る. 反応温度付近では $\mathrm{ZrO}_{2}$ の安定相は単斜晶であるが, アモルファス $\mathrm{Ni}-\mathrm{Zr}$ 合金を前駆体とした触媒ではかなり 多量の正方晶 $\mathrm{ZrO}_{2}$ 構造の酸化物が検出され, ニッケル を担持した正方晶 $\mathrm{ZrO}_{2}$ が高活性触媒であった ${ }^{16)}$. 正方 晶 $\mathrm{ZrO}_{2}$ 型酸化物は, $\mathrm{Ni}-\mathrm{Zr}$ 合金のジルコニウムが酸化さ れ $\mathrm{ZrO}_{2}$ 結晶が生じるとき, 同時に酸化されて生じる $\mathrm{Ni}^{2+}$ の一部も $\mathrm{ZrO}_{2}$ 結晶格子点を占めた複酸化物である. したがって，前駆体合金のニッケル含量が多いほど正方 晶 $\mathrm{ZrO}_{2}$ 型複酸化物が多くなり, 活性も向上する ${ }^{17)}$. し 
かし，ニッケルが多すぎると，触媒表面のニッケルが凝 集し, 活性点となる表面のニッケル原子数が減ってしま う.このため, 合金のニッケル濃度を上げて触媒活性を 上げるには限度がある。触媒活性の向上には，ニッケル 量を増さずに，正方晶 $\mathrm{ZrO}_{2}$ 型複酸化物を増すことが望 ましい。正方晶 $\mathrm{ZrO}_{2}$ 型複酸化物は, $\mathrm{Ni}^{2+}$ イオン以外に も 3 価の希土類元素イオンや $\mathrm{Ca}^{2+}$ イオン, $\mathrm{Mg}^{2+}$ イオン など $\mathrm{Zr}^{4+}$ イオンより低価数のイオンを含むことによって 安定化する， $\mathrm{Ni}-\mathrm{Zr}$ 合金に希土類元素を添加し，正方晶 $\mathrm{ZrO}_{2}$ 型酸化物を増すことによって, 触媒活性を著しく増 すことができた ${ }^{18)}$.またこれらの触媒を $\mathrm{CO}_{2}$ だけでなく CO も含むガスのメタン化に用いると，CO を 100\%優先 的にメタン化し, 残っている水素の分だけ $\mathrm{CO}_{2}$ をメタン 化することが判明している19).

\subsection{2 触媒と反応機構}

ここで, 正方晶 $\mathrm{ZrO}_{2}$ 型複酸化物がなぜ二酸化炭素の メタン化に有効であるかに触れよう． $\mathrm{CO}_{2}$ および $\mathrm{CO}$ の 吸着容量については，単斜晶 $\mathrm{ZrO}_{2}$ 型酸化物の方が，正 方晶 $\mathrm{ZrO}_{2}$ 型酸化物より $\mathrm{CO}_{2}$ が 1 桁以上, $\mathrm{CO}$ が $5 \sim 10$ 倍大きいことが知られている20)。このため， $\mathrm{CO}_{2}$ および $\mathrm{CO}$ の吸着が律速であるような $\mathrm{CO}_{2}$ および $\mathrm{CO}$ からメ夕 ノールを生成する場合, $\mathrm{Cu}$ 担持 $\mathrm{ZrO}_{2}$ を触媒として用い ると, 単斜晶 $\mathrm{ZrO}_{2}$ 型酸化物の方が, 正方晶 $\mathrm{ZrO}_{2}$ 型酸化 物より $\mathrm{CO}_{2}$ の反応で 4.5 倍, $\mathrm{CO}$ の反応で 7.5 倍それぞ れ速いことが報告されている21)。これに対し， $\mathrm{CO}_{2}$ およ び $\mathrm{CO}$ のメタン化には, 単斜晶 $\mathrm{ZrO}_{2}$ 型酸化物を担体と して用いると活性が低く, 正方晶 $\mathrm{ZrO}_{2}$ 型複酸化物を担 体として用いることが，高速に反応を進める条件である. このことから明らかなように， $\mathrm{CO}_{2}$ および $\mathrm{CO}$ のメタン 化は $\mathrm{CO}_{2}$ および $\mathrm{CO}$ の触媒への吸着が律速ではない.

$\mathrm{CO}_{2}$ および $\mathrm{CO}$ のメタン化の触媒活性を向上するのに は，正方晶 $\mathrm{ZrO}_{2}$ 型複酸化物を増すことが有効であった。 正方晶 $\mathrm{ZrO}_{2}$ 構造を安定化させるには, 酸化物の主成分 である $\mathrm{Zr}^{4+}$ より価数の小さい元素を添加することであ る。これは, $\mathrm{Zr}^{4+}$ より価数の小さい元素が結晶に含まれ る分だけ結晶格子内の酸素空孔が増し, 酸素の充填構造 である結晶の構造が変形し, 正方晶構造が安定になるた めであった。この酸素空孔は, 䨌囲気中の酸素との相互 作用が大きい。例えば， $\mathrm{Y}^{3+} て ゙$ 安定化された正方晶 $\mathrm{ZrO}_{2}$ 型複酸化物を水蒸気䨌囲気中 $250^{\circ} \mathrm{C}$ で熱処理すると, 酸 素空孔分だけ $\mathrm{H}_{2} \mathrm{O}$ を吸収して重量を増し，単斜晶に変態 することが知られている ${ }^{22)}$. 酸素空孔は, 䨌囲気の酸素 すなわち, $\mathrm{CO}_{2}$ あるいは $\mathrm{CO}$ の酸素との相互作用が大き いため, $\mathrm{CO}_{2}$ あるいは $\mathrm{CO}$ は $\mathrm{C}=\mathrm{O}$ 結合が弱められ, 雾 囲気の水素と直接反応し, $\mathrm{CH}_{4}$ および $\mathrm{H}_{2} \mathrm{O}$ を生じるもの と考えられる。

\subsection{3 量産用触媒}

アモルファス $\mathrm{Ni}-\mathrm{Zr}$ 合金を触媒前駆体として用いるこ とによって, 正方晶 $\mathrm{ZrO}_{2}$ 型複酸化物にニッケルを担持 したものが，二酸化炭素のメタン化に高活性な触媒であ ることを見いだすことができた。しかし，アモルファス 合金は触媒の大量生産には適さない。実際には，アモル ファス合金が必要なのではなく, 正方晶 $\mathrm{ZrO}_{2}$ 型複酸化 物が必要であることが分かってきた。 そこで，ジルコニ アヒドロゾルに, 希土類元素の塩を添加して焼成するこ とによって正方晶 $\mathrm{ZrO}_{2}$ 型複酸化物を造り，これにニッ
ケルを含浸させる方法で触媒を得て, 十分に高性能の触 媒が得られることを確認した23)

さらに簡便な触媒作製法として，ジルコニアヒドロゾ ルに, 希土類元素の塩と共にニッケル塩も添加して焼成 することによって正方晶 $\mathrm{ZrO}_{2}$ 型複酸化物と $\mathrm{NiO}$ の混合 物を造り，表面の $\mathrm{NiO}$ を水素で還元することによって， $\mathrm{Ni}$ を正方晶 $\mathrm{ZrO}_{2}$ 型複酸化物に担持した高活性触媒を得 ることができた。

図 $8^{24)}$ は種々の温度で焼成した 50 原子 $\% \mathrm{Ni}-50$ 原子 $\%$ $\left(\mathrm{Zr}_{0.833} \mathrm{Sm}_{0.167}\right)$ 触媒の二酸化炭素のメタン化に対する活性 の反応温度による変化を示す.メタン生成反応は, 発熱 反応であるが，常圧では $350^{\circ} \mathrm{C}$ 付近が最適な反応温度で あって，それ以上高いと，逆反応が起こり，転換率は低 下する。一方，触媒活性は焼成温度が $650 \sim 800^{\circ} \mathrm{C}$ で最高 になっている。これについては後に述べる。

図 924) は, $\mathrm{Ni}$ と $\mathrm{Zr}+\mathrm{Sm}$ との量比を 3 種類に変え, さ らに $\mathrm{Zr} / \mathrm{Sm}$ 比を変えた試料の $\mathrm{CO}_{2}$ 転換率の変化である. ニッケルが多すぎると十分な活性が得られないが，ニッ ケルを 40 原子\%まで減らすと活性点が不足して，転換 率は低下していたので，50 原子 \% $\% \mathrm{Ni}^{-50}$ 原子 $\%(\mathrm{Zr}+\mathrm{Sm})$ 程度が最適なようである。また，一定の焼成温度の触媒 では $\mathrm{Zr} / \mathrm{Sm}$ 比が増す程，活性は増すが，過剩な $\mathrm{Zr} / \mathrm{Sm}$

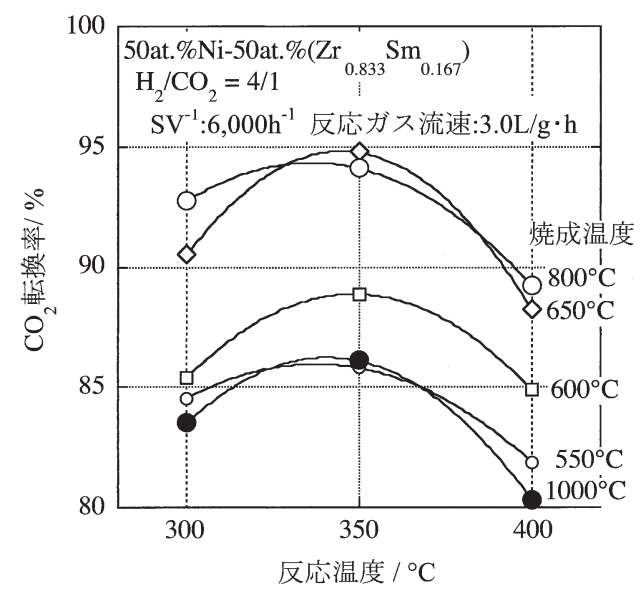

図 8 種々の温度で焼成した 50 原子 \% Ni-50 原子 \% $\left(\mathrm{Zr}_{0.833}\right.$ $\left.\mathrm{Sm}_{0.167}\right)$ 触媒の二酸化炭素のメタン化に対する活性の反応 温度および触媒焼成温度による変化 ${ }^{24)}$

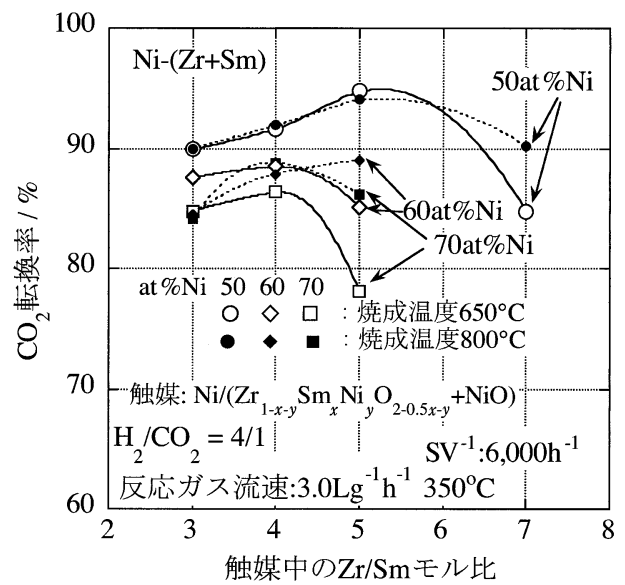

図 $9 \mathrm{Zr} / \mathrm{Sm}$ 比を変えた 3 種類の $\mathrm{Ni}-\mathrm{Zr}-\mathrm{Sm}$ 触媒の組成と焼成 温度による二酸化炭素のメタン化に対する活性の変化 ${ }^{24)}$ 
比は有害である. 正方晶 $\mathrm{ZrO}_{2}$ 型複酸化物を安定にする サマリウムが十分に含まれる組成範囲では，Zr/Sm 比を 増して正方晶 $\mathrm{ZrO}_{2}$ 型複酸化物が増す程, 活性が向上す るが，過剩の $\mathrm{Zr} / \mathrm{Sm}$ 比は正方晶 $\mathrm{ZrO}_{2}$ 構造を安定にする サマリウムの不足を来すため活性が低下してしまう。

このように, $\mathrm{Ni} と \mathrm{Zr}+\mathrm{Sm}$ との量比, $\mathrm{Zr} / \mathrm{Sm}$ 比および 焼成温度による活性の変化は, 正方晶 $\mathrm{ZrO}_{2}$ 型複酸化物 の量ならびに, 正方晶 $\mathrm{ZrO}_{2}$ 型複酸化物に含まれる, サ マリウムおよびニッケルの量による変化である。これに 関連して，焼成温度と組成による正方晶 $\mathrm{ZrO}_{2}$ 型結晶の 格子面間隔の変化を図 $10^{24)}$ に示す。図 10 では $\mathrm{Ni}$ と $\mathrm{Zr}+\mathrm{Sm}$ との量比を変えさらに $\mathrm{Zr} / \mathrm{Sm}$ 比を変えた試料に ついて，焼成温度と共に正方晶 $\mathrm{ZrO}_{2}$ 型複酸化物の格子 が広がることを示し，また，ニッケル総量が多い70 原 子\%の方が 50 原子\%のものより $\mathrm{ZrO}_{2}$ 型酸化物の格子が 狭くなることを示している.さらに, $\mathrm{Zr} / \mathrm{Sm}$ 比が小さく, サマリウムが多い程, $\mathrm{ZrO}_{2}$ 型酸化物の格子が広がってい る. $\mathrm{Sm}^{3+}$ イオン, $\mathrm{Zr}^{4+}$ イオン, $\mathrm{Ni}^{2+}$ イオンの半径はそれ ぞれ, $0.0964 \mathrm{~nm}, 0.079 \mathrm{~nm}, 0.069 \mathrm{~nm}$ である. ニッケル 含量が 50 原子 \%より 70 原子\%と多く, $\mathrm{ZrO}_{2}$ 型酸化物が, 最も小さい $\mathrm{Ni}^{2+}$ イオンを多く含む程 $\mathrm{ZrO}_{2}$ 型複酸化物の 格子は縮まっている. また, $\mathrm{Zr} / \mathrm{Sm}$ 比が $5,4,3$ と小さく なるほど, $\mathrm{ZrO}_{2}$ 型複酸化物中の $\mathrm{Sm}^{3+}$ イオン濃度が高く なり, $\mathrm{ZrO}_{2}$ 型複酸化物の格子が広がっている. 焼成温度 を上げると, $\mathrm{ZrO}_{2}$ 型酸化物のまわりの結晶を構成してい ないサマリウムが $\mathrm{ZrO}_{2}$ 構造にさらに取り込まれ $\mathrm{ZrO}_{2}$ 型 複酸化物の格子が広がると共に, 酸素空孔の量も増す. 図 8 において，焼成温度が上昇すると，活性が向上する のは酸素空孔濃度が増大したためである.このように焼 成温度の上昇は酸素空孔濃度を増し, 触媒活性の向上に 有効である。

しかし．実際には，焼成温度が高過ぎる $1000^{\circ} \mathrm{C}$ では， 図 8 に見られるように，活性が低下してしまう。図 $11^{24)}$ に示すように焼成温度の上昇と共に, 正方晶 $\mathrm{ZrO}_{2}$ 型酸 化物の結晶粒径は直線的に増大する。一例として, BET 表面積を図 1224) に示すように, 結晶粒径の増大に応じて 触媒に必要な特性である BET 表面積, 金属分散度, 水 素の取り込み量が減少してしまう24)。結局, 焼成温度の 上昇は, 正方晶 $\mathrm{ZrO}_{2}$ 型酸化物中の正方晶構造安定化元 素の濃度したがって酸素空孔濃度を増して個々の触媒の 活性は増大させるが，表面における触媒活性点の密度を

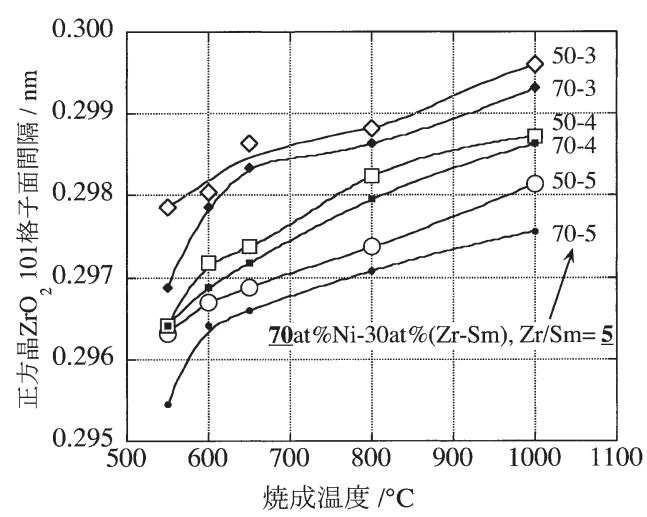

図 $10 \mathrm{Ni}^{-}(\mathrm{Zr}+\mathrm{Sm})$ 触媒を構成する正方晶 $\mathrm{ZrO}_{2}$ 型複酸化物の 101 格子面間隔の焼成温度による変化 ${ }^{24}$

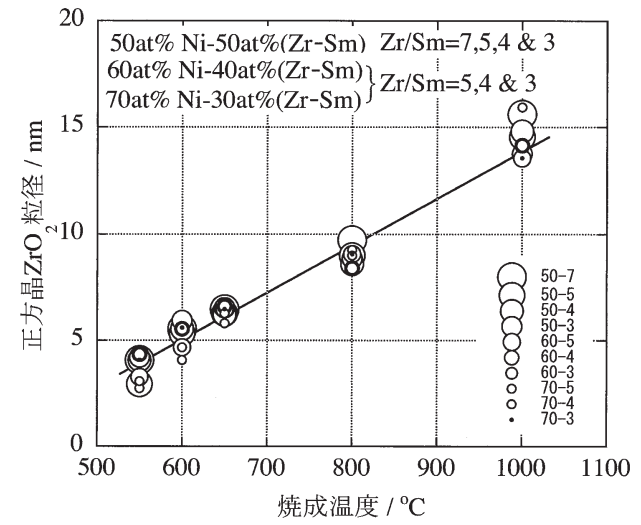

図 $11 \mathrm{Ni}^{-}(\mathrm{Zr}+\mathrm{Sm})$ 触媒を構成する正方晶 $\mathrm{ZrO}_{2}$ 型結晶の 101 反射から求めた粒径の焼成温度による変化 ${ }^{24)}$

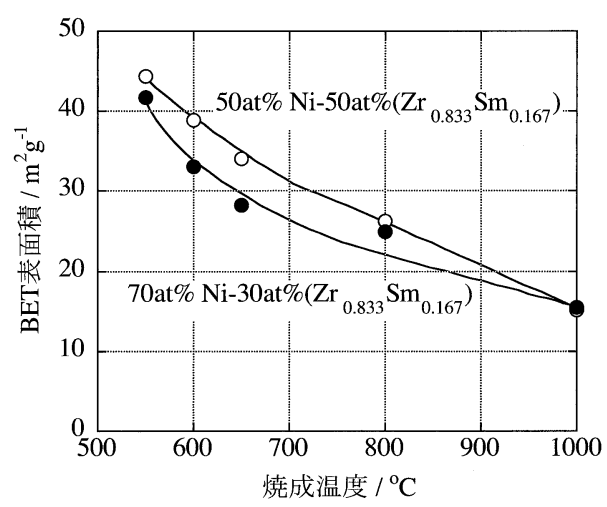

図 1250 原子 $\% \mathrm{Ni}-50$ 原子 $\%\left(\mathrm{Zr}_{0.833} \mathrm{Sm}_{0.167}\right)$ 触媒扔よび 70 原 子 \% Ni-30 原子 \% $\left(\mathrm{Zr}_{0.833} \mathrm{Sm}_{0.167}\right)$ 触媒の焼成温度による $\mathrm{BET}$ 表面積の変化 ${ }^{24}$

減らしてしまうため, 焼成温度 650 ～ $800^{\circ} \mathrm{C}$ が最適となっ ている.この結果, 酸素空孔濃度が可能な限り高い $\mathrm{ZrO}_{2}$ 型複酸化物, この場合は $\mathrm{Zr}_{1-x-y} \mathrm{Sm}_{x} \mathrm{Ni}_{y} \mathrm{O}_{2-0.5 x-y}$ の表面に 十分にニッケルが分散した構造が最適の触媒ということ になる。

このように，ジルコニアヒドロゾルにニッケル塩と共 に, 正方晶 $\mathrm{ZrO}_{2}$ 構造を安定にする元素の塩を添加して 焼成し, $\mathrm{NiO}$ と正方晶 $\mathrm{ZrO}_{2}$ 型複酸化物の混合体を作製 し, これに水素処理を施して表面の $\mathrm{NiO}$ を還元する方法 は，理想的触媒を量産する方法であることが判明した。 しかし, 正方晶 $\mathrm{ZrO}_{2}$ 構造を安定にする元素として希少 な希土類元素を使うことは，世界に燃料を供給する方法 としては好ましくない。希土類元素でなくても， $\mathrm{Ca}^{2+}$ あ るいは $\mathrm{Mg}^{2+}$ イオンを添加しても, 正方晶 $\mathrm{ZrO}_{2}$ 構造を安 定にすることができる.

一例として, ジルコニアヒドロゾルに硝酸ニッケルと 硝酸カルシウムを添加して焼成し, 還元して得られた触 媒の性能を図 1325) に示す. カルシウムを添加して正方晶 $\mathrm{ZrO}_{2}$ 構造を安定にした触媒も, 二酸化炭素のメタン化に 十分に高い活性を備えていることが明らかである。

\section{5. 産業化に向かって}

キーマテリアルを得られるようになって，1995 年には 東北大学金属材料研究所屋上に, 太陽電池, 電解プラン 


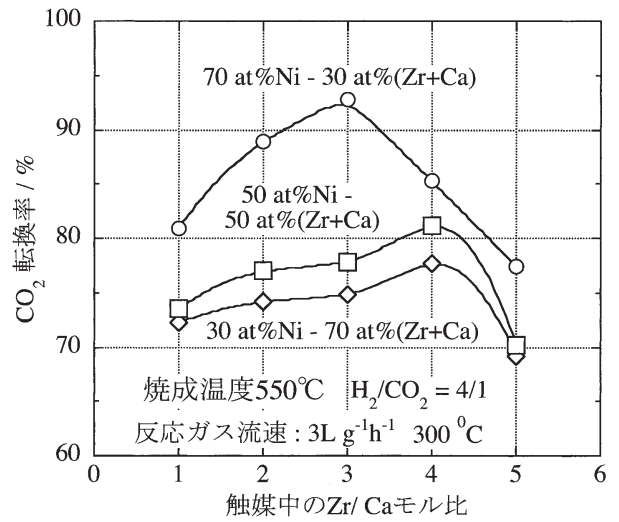

図 $13 \mathrm{Zr} / \mathrm{Ca}$ 比を変えた 3 種類の $\mathrm{Ni}-\mathrm{Zr}-\mathrm{Ca}$ 触媒の組成による 二酸化炭素のメタン化に対する活性の変化 ${ }^{25}$

ト, 二酸化炭素メタン化プラント, 燃焼器をつなぐグロ ーバル二酸化炭素リサイクル実証プラントを建造するこ とが出来た。これによって, 太陽エネルギーが得られさ えすれば，遠方の燃焼器でメタンの形でこれを燃やすこ とが出来，二酸化炭素は大気に排出されずに燃料の原料 として循環して繰り返し使えることが実証された。

さらに，2003 年には，4 $\mathrm{m}^{3} \mathrm{~h}^{-1}$ の速度で水素を造り, これを用いて $1 \mathrm{~m}^{3} \mathrm{~h}^{-1}$ の速度でメタンを造る産業規模の プラントを東北工業大学に造ることができた.

再生可能エネルギーをメタンの形で世界に供給する技 術的な基礎はできあがっている。しかし，一次エネルギ 一である天然ガスが容易に手に入る時代に，再生可能エ ネルギーを一次エネルギーとして電気，水素をへて造ら れる四次エネルギーであるメタンは，エネルギー変換の 度に費用がかさむため, 現在は，まだコストの上で天然 ガスと競走できない. しかし，前述のように，燃やすも のがなく，温暖化だけが深刻な状態の到来はそう遠くな い. 先に述べたように, インドネシアが国内の需要に応 えるため石油の輸出を控えるということがもう始まろう としている．15２0 年後には，世界中で燃料の輸出規制 は行われるであろう。これに備えるためには，今すぐ手 が届く技術を開発しなければならないが，ここに述べた 技術以外に, 大量に再生可能エネルギー起源の燃料を供 給できる今手が届く技術を, 筆者らは考えつかない。現 在は, 最終製品であるメタンの価格を下げるため, キー マテリアルやシステムの改良に努め, あわせて大規模産 業プラントの準備を進めている。

産業は手を出しにくい技術であっても, 今産業化を始 めないと間に合わないことも事実である。今年 2012 年 の 1 月末には, 外国の大きな石油天然ガス会社と日本の 二つの企業との間で, 天然ガスに含まれる多量の二酸化 炭素を再生可能エネルギー起源の電力で得られる電解水 素を使ってメタンに変える産業技術の協同開発の協定が 結ばれた、筆者らが 20 年以上研究開発を行って来た技 術を基に, 再生可能エネルギーだけで世界が生きて行く ことが出来る新しいエネルギーの時代の夜明けが近づき つつあることを実感している。

\section{謝辞}

この稿は, 著者の一人橋本功二が The Electrochemical Societyの Olin Palladium Award を受賞したことから依頼
されたと聞いています．橋本功二が，このような研究を することが出来，今なおこのような研究に関わっている ことが出来るのは, 優秀な仲間と卒業生なしにはあり得 ないことでありますし，さらには，このような研究を支 援して下さる国内外の多くの方々や企業のお㓌です。 ま た，東日本大震災の折には，沢山のご支援とお心遣いを 戴きました。ここに，誌上をお借りして東心よりお礼申 し上げます。

\section{参 考 文 献}

1) K. Hashimoto, N. Kumagai, Z. Kato and K. Izumiya, Zairyoto-Kankyo, 58, 250 (2009).

2) http://www.eia.gov/tools/a-z/index.cfm

3) http://www.world-nuclear.org/info/inf75.html

4) http://www.re-policy.jp/keito/2/030912_09.pdf\# search

5) http://www.re-policy.jp/keito/2/030912_06.pdf\# search

6) K. Hashimoto, Kinzoku, 63 [7] 5 (1993).

7) K. Izumiya, E. Akiyama, H. Habazaki, N. Kumagai, A. Kawashima and K. Hashimoto, Electrochimica Acta, 43, 3303 (1998)

8) K. Fujimura, K. Izumiya, A. Kawashima, H. Habazaki, E. Akiyama, N. Kumagai and K. Hashimoto, Journal of Applied Electrochemistry, 29, 765 (1999).

9) N. A. Abdel Ghany, N. Kumagai, S. Meguro, K. Asami and K. Hashimoto, Electrochimica Acta. 48, 21 (2002).

10) A. A. El-Moneim, N. Kumagai, K. Asami and K. Hashimoto, Electrochemical Society Transaction, 1 [4] 491 (2006).

11) A. A. E1-Moneim, K. Izumiya, N. Kumagai and K. Hashimoto, unpublished data.

12) Z. Kato, N. Kumagai, K. Izumiya and K. Hashimoto, Applied Surface Science, 257, 8230 (2011).

13) S. Meguro, T. Sasaki, H. Katagiri, H. Habazaki, A. Kawashima, T. Sakaki, K. Asami and K. Hashimoto, Journal of Electrochemical Society, 147, 3003 (2000).

14) P. R. Zabinski, S. Meguro, K. Asami and K. Hashimoto, Materials Transaction, 44, 2350 (2003).

15) H. Habazaki, T. Tada, K. Wakuda, A. Kawashima, K. Asami and K. Hashimoto, "Corrosion, Electrochemistry and Catalysis of Metastable Metals and Intermetallics”, C. R. Clayton and K. Hashimoto Eds., the Electrochemical Society, p.393 (1993)

16) M. Yamasaki, H. Habazaki, T. Yoshida, E. Akiyama, A. Kawashima, K. Asami and K. Hashimoto, Applied Catalysis A : General, 163, 187 (1997).

17) M. Yamasaki, H. Habazaki, T. Yoshida, M. Komori, K. Shimamura, E. Akiyama, A. Kawashima, K. Asami and K. Hashimoto, Studies in Surface Science and Catalysis, 114, 451 (1998)

18) H. Habazaki, T. Yoshida, M. Yamasaki, M. Komori, K. Shimamura, E. Akiyama, A. Kawashima and K. Hashimoto, Studies in Surface Science and Catalysis, 114, 261 (1998).

19) H. Habazaki, M. Yamasaki, B.-P. Zhang, A. Kawashima, S. Kohno, T. Takai and K. Hashimoto, Applied Catalysis A : General, 172, 131 (1998).

20) K. Pokrovski, K. T. Jung and A. T., Bell, Langmuir, 17 [14] 4297 (2001).

21) K. T. Jung and A. T., Bell, Catalysis Letters, 80 [1-2] 63 (2002).

22) N. Narita, Database of Grants-in-Aid for Scientific Research, Japan, http://kaken.nii.ac.jp/ja/p/63550474/1988/3/ja

23) H. Habazaki, M. Yamasaki, A. Kawashima and K. Hashimoto, Applied Organometallic Chemistry, 14, 803 (2000).

24) H. Takano, K. Izumiya, N. Kumagai and K. Hashimoto, Applied Surface Science, 257, 8171 (2011).

25) H. Takano, K. Izumiya, N. Kumagai and K. Hashimoto, unpublished data.

(2012 年 3 月 2 日受理) 
要旨

1990 年から 2008 年の世界のエネルギー消費量を外持ると, 石油, 天然ガス, ウラン, 石炭の世界の 資源はそれぞれ 2040 年, 2046 年，2048 年㧍よび 2054 年までに使い尽くされてしまう。世界中の人々が 生き続けるためには, 再生可能エネルギーから造られる断続・変動する電力を, 使うことが出来る燃料の 形で世界中の人々に供給する必要がある。筆者らは，再生可能エネルギー起源の電力を用い，電解で水素 を生成し, 二酸化炭素と反応させ, メタンの形で供給するグローバル二酸化炭素リサイクルを提案して来 た。このために, 海水電解による水素製造のための省エネルギーカソードおよび塩素を発生せず酸素のみ を発生するアノード, ならびに二酸化炭素のメタン化のための触媒を創り, 産業規模のパイロットプラン 卜を造って来た。本稿では最近の進歩や知見を記述した。この産業化が進んでいる.

キーワード 再生可能エネルギー, メタン供給, $\mathrm{CO}_{2}$ リサイクル, 電解水素生成, $\mathrm{CO}_{2}$ メ夕ン化, 燃 料涸渇, 世界中が生き延びること 